
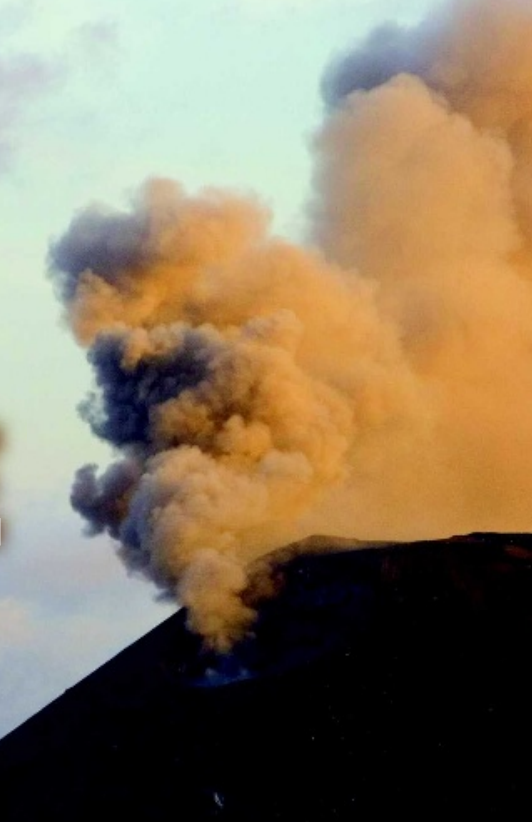

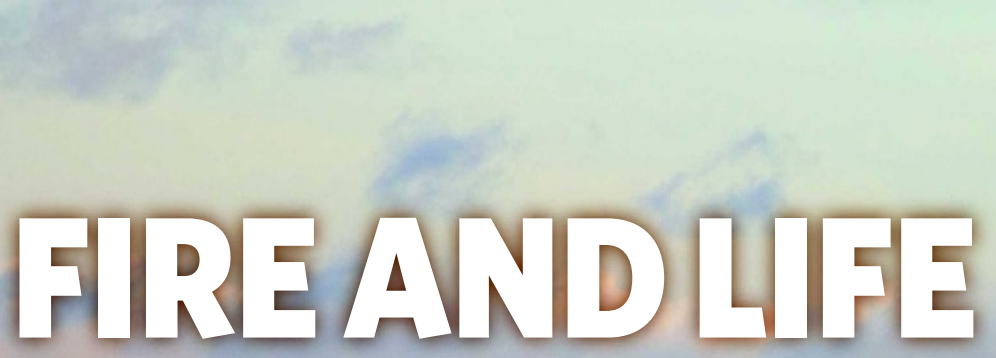 \\ Recent eruptions and field expeditions may herald a return to glory for the Son of Krakatau. Jerry Guo explores what the 78-year-old island has to offer.

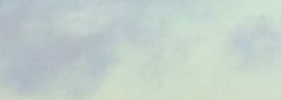
prouting 300 metres above the sea, the
cone of Anak Krakatau teases voyagers with anticipation. The volcano spews hot steam from an off-centre crater, as the surf crashes against the lava flows that have cooled around the base. In this contest between water and rock, the rock is winning. As the island gains a foothold in the vast Pacific, it provides scientists with a rare glimpse at how life takes hold in a newborn ecosystem.

Anak Krakatau - 'child of Krakatau' in Indonesian - is one of the most striking geological oddities of the modern era: an island that first rose up out of the sea in 1927 and receded and reappeared three times until it established itself permanently above sea level in 1930. It has arisen from the centre of the deep underwater caldera left by the original Krakatau volcano, which blew itself to pieces in 1883 in one of the most powerful and devastating eruptions in recorded history. The explosions and the tsunamis they created killed 36,000 people.

This patch of rock three kilometres square and sandwiched in the strait between Java and Sumatra has earned itself a reputation as a laboratory for observing how life arrives, endures and perishes on an island. In the 1980s and early 1990s, research conducted there on the 170 plant, 40 bird and dozens of bat and insect species, came to define much of what is known about island colonization, ecological disturbance

and community dynamics. Anak Krakatau became the testing ground - and flashpoint - for many textbook principles of island biogeography.

Then interest began to wane. Scientists packed their bags and turned to other hotspots - the Galapagos, Seychelles, another newborn island in Iceland. "The work that was easy was quickly done," explains Richard Field, an ecologist at the University of Nottingham, UK. Research on Anak went through a 'quiet phase.' Even volcanic activity eased up.

But a slew of research projects, led by teams from Britain, Germany, Japan and Indonesia, could mark the start of a second age for the island.

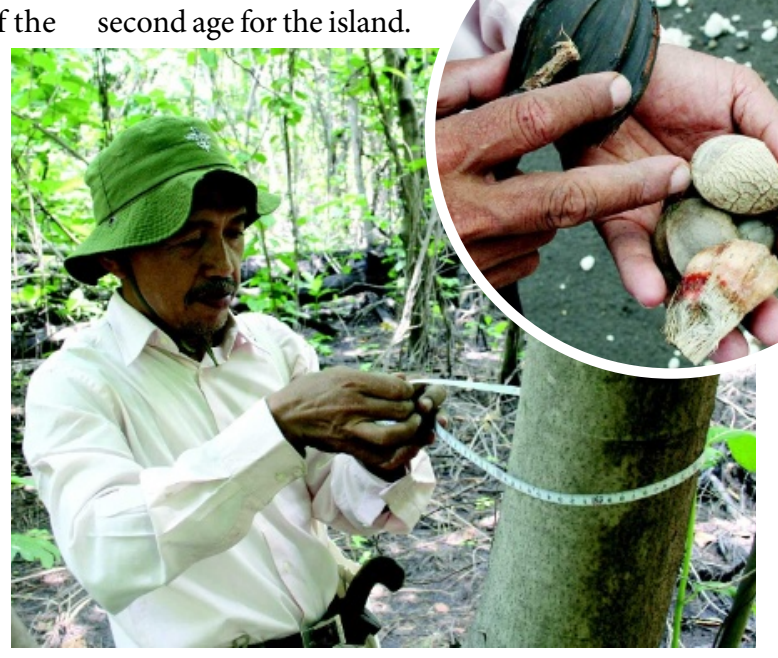

Tukirin Partomihardjo evaluates the flora of Anak Krakatau.
"Anak still has a lot to teach us," says Field. "It's ¿ one of the classic natural experiments."

Eruptions throughout November - the most violent in more than a decade - recaptured the world's attention with news that Anak was rattling windowpanes in western Java, some 40 kilometres away, and producing 3-kilometre-high ash plumes and spewing showers of lava bombs. The volcano has remained active ever since, with eruptions this January, April, June and July, according to Australia's Darwin Volcanic Ash Advisory Centre and Indonesia's Center of Volcanology and Geological Hazard Mitigation. It is during a lull between eruptions that Tukirin Partomihardjo, a wiry botanist wearing a neatly pressed white-collared dress shirt and sporting a machete wades onto the black-sand beach at Anak. The 56-year-old 'King of Krakatau' has arrived.

It's hard to take a step on Anak without crushing some sort of life: blue-ish ghost crabs, armies of ants, fast-multiplying casuarina seedlings and even a coconut that has sprouted an impressive-looking stem. These are some of Anak's colonizers, which every day continue to launch attacks on the island. "There is a constant struggle here," says Partomihardjo, who works for Indonesia's Bogor 
Herbarium, referring to these pioneering species' battle with the elements.

Much of what biologists can say about the fate of such species came from data on Anak. The textbook case-study of this 'species succession' began just 9 months after the final 1930 eruption, when a single spider was found clinging to a rock. Fungi and other microbes soon followed and, in a decade, the lower slopes began to be covered with a grassland savannah that was dominated by sugarcane. Life brought more life. At some point, seed dispersal by animals - land crabs, monitor lizards and countless species of birds - outpaced that by sea. The emerging mixed forest, with its nooks and perches, attracted more birds and ultimately bats, explains Field. Wind-dispersed species, such as orchids, then moved farther inland. The rest is history. "Anak played a big part in helping people understand colonizing processes," says Field.

In the early 1990s, Partomihardjo showed that banks of seeds that had been buried by ash or by crabs on the shore for as long as six decades could contribute to the first waves of life on a barren landscape ${ }^{1}$. Now, one of his ongoing projects is to examine the diversity of the beach seed bank. In just one day, he finds some 30 species of seed of varying descriptions: green cactus-like, flat and pea-shaped, walnut-shaped. Blown or having floated in from the nearby 'stepping stone' islands as well as from Java and Sumatra, these specimens litter the beach. Not all will survive. Partomihardjo holds up a dark, oblong mangrove seed and shakes his head. "This can't survive here." The rocky, wavedashed coast is just too inhospitable for the plant to take root and thrive.

\section{Death and rebirth}

Heading into a modest jungle on the eastern side of the island, Partomihardjo walks through a panoply of dominant casuarinas, waist-high grasses, ferns and 30-metre-high fig trees. It's hard to imagine that this was all under water a mere 78 years ago. The forest has bald spots, though, where recent lava flows have wiped out the newly emergent vegetation. "What's unusual is that the island keeps getting disturbed by volcanic activity," says Field. These eruptions can reset the clock on the succession process, yielding valuable data on ecological disturbance and recovery. But the eruptions also make continuous monitoring difficult, if not life-threatening. One of Partomihardjo's colleagues died on the island during a monitoring expedition in the 1990s.
Last September, a team of 11 field biologists, led by Partomihardjo and Field, erected a network of 21 monitoring plots on Anak. They tagged and mapped every tree within the $20 \times 20$ metre plots to gather long-term data on the forest's health and succession dynamics. The eruptions have wreaked havoc on many parts of the island. "Many trees have died," he says, blaming the ash that has covered much of the forest. "But this place will recover." consortium of Japanese research groups led by Kagoshima University completed a threeyear study of insect communities on Anak, including wasps, bees, ants, termites and galling arthropods. The team found 16 species of wasp and 18 species of ant that had not previously been documented on the island, and hopes to publish its findings soon. "Anak is still very interesting for us," says Suzuki Eizi. "We need to monitor it for a long period."
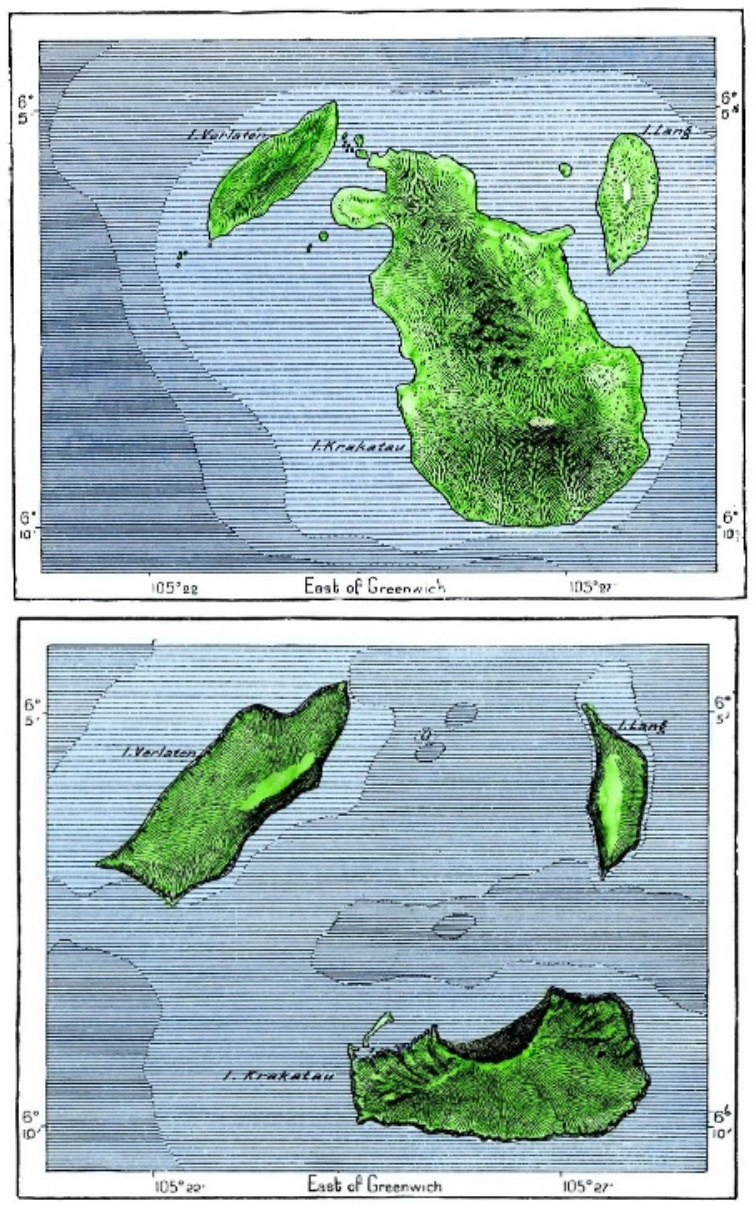

Maps of Krakatau before (top) and after (bottom) its 1883 eruption show how volcanic activity reshaped the landscape. Anak Krakatau rose in the centre of three islands that remained.

\section{Step by step}

Field's team also started surveying trees, birds and ants last year, and have several papers in preparation. One important finding, for instance, is that colonization and extinction, at least in plants and birds, could be less random than previously thought. In 1967, Robert MacArthur and E. O. Wilson cited the randomness of bird colonization on Krakatau as a prime example for their classic theory of island biogeography - that species diversity grows along a smooth curve to ultimately reach equilibrium. Research conducted by Whittaker on Krakatau in the 1990s — and picking up again now - suggests that the equilibrium model may be too simplistic. "Overall, a complex picture of ecosystem assembly is emerging from the Krakatau islands, one that suggests that island colonization is essentially a special case of succession," explains Field, who subscribes to the emerging school of thought that island biogeography is in part a deterministic process ${ }^{2}$. Take Anak's fig trees. Each species depends on specific birds, bats and wasps for seed dispersal and reproduction. "You can't get figs without the wasps and you can't get the wasps without the figs. Our results don't fit with the MacArthur-Wilson idea that both colonization and extinction are equally likely for any species," says Field.

Furthermore, later research showed that colonization seemed not to follow another commonly accepted theory that

Partomihardjo is the world's leading expert on the Krakatau islands. He first visited them in 1981 during a training seminar, and has been back some 30 times since, leading almost all foreign research expeditions there. "He has spent longer working on Anak than any other biologist living or dead and knows it more intimately than anyone else," says Robert Whittaker, an ecologist at the University of Oxford, UK, who is himself an authority on the islands.

Research at Anak has been pushing ahead on numerous fronts. This March, a terrestrial life comes from nearby 'stepping stone' islands, perhaps because the environments were so different. One study ${ }^{3}$ revealed that Old World fruit bats can retain viable seeds in their guts long enough to transport them hundreds of kilometres, skipping over small nearby islands in the process.

Geologists, too, have been showing an interest in Anak's activity. In 2005, German and Indonesian volcanologists rigged the island with three remote monitoring stations. They hope to use sophisticated neural network programs ${ }^{4}$ to analyse the dizzying array of 


\section{Island uprising}

New islands have popped up all over the globe. They are a centre for study, and sometimes controversy.

\section{Warming Island, Greenland}

Discovered in $\mathbf{2 0 0 5}$ by US explorer Dennis Schmitt

- Formerly believed to be a peninsula, retreating ice revealed an island 644 kilometres north of the Arctic circle.

- Focus of a 2007 documentary by Utah film-maker Eric Ristau, and of arguments by a climate sceptic who points to a map in a 1957 book as evidence that this isn't a 'new' island created by global warming.

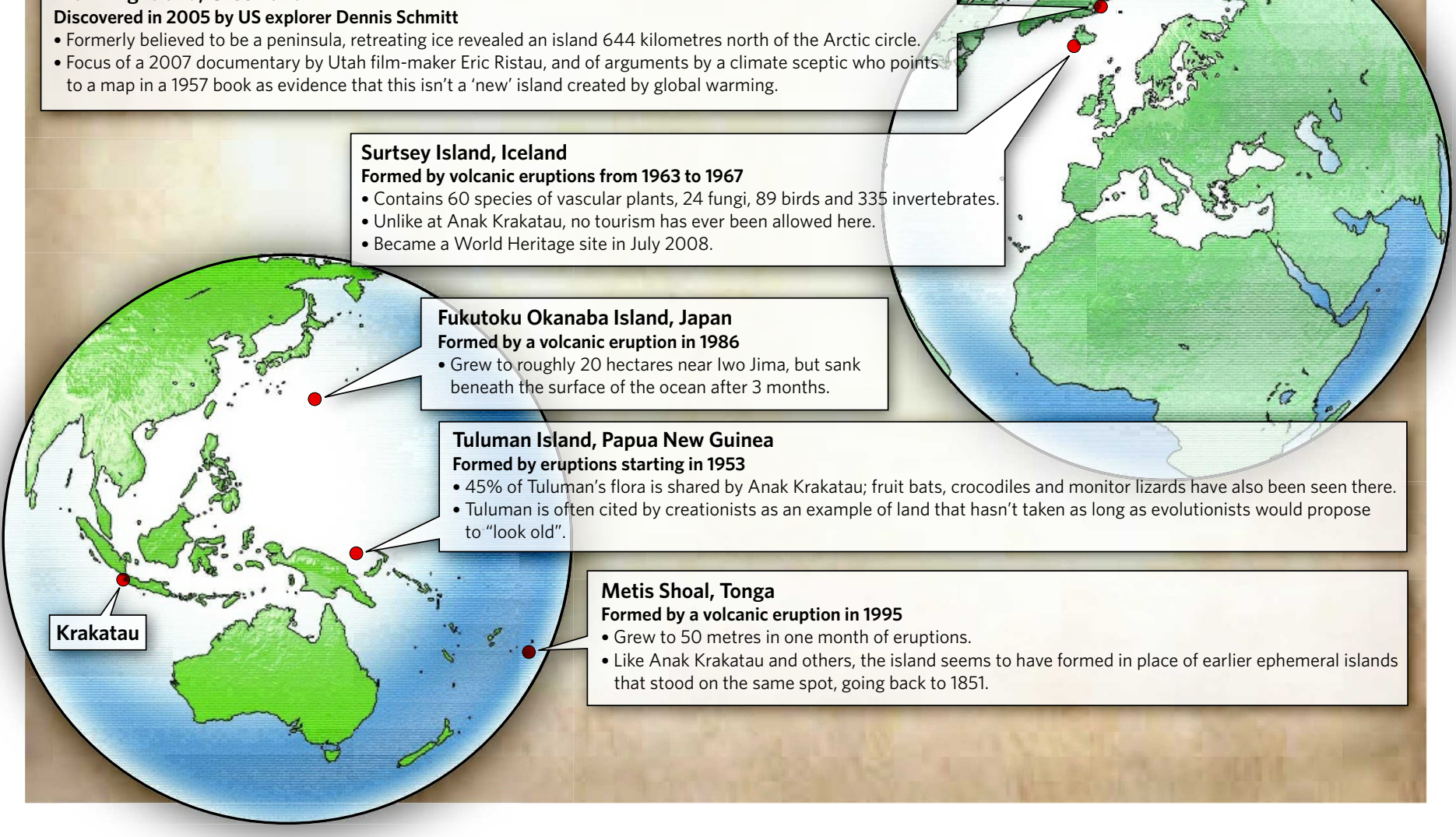

data - meteorological, chemical, seismic - recorded by the stations to predict future eruptions. The raw numbers are also broadcast online in real-time, including a video feed.

\section{Rewriting history}

Meanwhile, Ken Wohletz, a volcanologist from Los Alamos National Laboratory in New Mexico, wants to restart a controversial project that claimed to have found a possible mega-eruption in Krakatau's past. He cites evidence from tree rings in Europe, ice cores in Greenland and ash deposits from the Sundra Straits that suggest a massive eruption in AD 535 - 20 times bigger than the 1883 event - precipitated the Dark Ages through "climate stabilization lasting years or perhaps decades". He theorizes that the AD 535 eruption could have dramatically altered the climate, affecting crops and the spread of disease, and triggering the collapse of several civilizations in Indonesia, South America and Persia, but concedes that the supporting data, for the moment, are sketchy. "It will be hard to find more evidence to date such an eruption," Wohletz says.

For one, his radiocarbon datings yielded a wide-open time window: from $6600 \mathrm{BC}$ to AD 1215; critics also point to the Byzantine Empire, which went through a Golden Age during this time, as a counterexample of a global doomsday. "It will take years and years to put together the full story," he says.

Such attention is a testament of the singular importance of the Krakatau islands to the scientific community, given that 'new islands' appear (and disappear) with some regularity. Since Anak Krakatau achieved permanent status in 1930, several new additions have been made to this geological family (see 'Island uprising'). The only new island to receive anywhere close to Anak's scientific scrutiny has been Surtsey, off the coast of Iceland, a volcano strikingly similar in shape, size and geology to Anak. Despite its inaccessible location, Surtsey has a leg up on Anak in one crucial aspect: it has an 18-year-old continuous data record based on 25 permanent plots, with monitoring trips every July. "The colonization on Anak has not been followed as frequently as here," says Borgthor Magnusson, a plant ecologist from the Icelandic Institute of Natural History in Reykjavik and leader of biological research on the island.

Although colonization of Surtsey has followed the classic path taken by Anak in many respects, Icelandic biologists have, in the past two decades, picked up on a distinct difference: the importance of birds to the island's health and growth. "The gull colony [some 200 breeding pairs] has a big impact," says Magnusson, citing its role in seed transport, soil fertilization and habitat creation. "We're still experiencing this phase of colonization."

Back at Anak, the Sun is about to set. Partomihardjo eyes the summit indecisively - a longstanding government directive warns people against going near the active cone. "Why not," he resolves. "Let's go."

As he climbs nimbly towards the top, he recounts one particularly close call back in the 1990s, when he got caught during an eruption. "Big stones were falling all around me," he says. Then he pauses and points to an old monitoring station nearby that was crushed by lava bombs the size of basketballs. "I thought I was going to die."

At dusk, he almost reaches the crater ridge (which he claims has grown 100 metres since his visit last October). But without a gas mask, he decides to turn back. Never mind the scorching ground. Still, even in this desolate landscape, with its crags and loose soil, he notices a rousing sight on the way down: a single pioneering shrub clinging bravely to life, its purple flowers in full bloom.

Jerry Guo is a freelance writer in New Haven, Connecticut, reporting from Indonesia.

1. Whittaker, R. J. et al. Biotropica 27, 346-354 (1995).

2. Ward, S. A. \& Thornton, I. W. B. Glob. Ecol. Biogeogr. 9, 7-18 (2000).

3. Shilton, L. A., Altringham, J. D., Compton, S. G. \& Whittaker, R. J. Proc. R. Soc. B 266, 219-223 (1999).

4. Ibs-von Seht, M. \& Kniess, R. Geophys. Res. Abs. 9, 03440 (2007). 